\title{
The application of pragmatic principles in competitive business writing
}

\author{
Haihong $\mathrm{Wu}^{*}$ \\ College English Teaching and Research Section of General Studies Department, Nanchang Institute of Science \\ and Technology, Nanchang, Jiangxi, China
}

\begin{abstract}
Business English writing, as an important means of communication, plays a vital role in international business communication. And pragmatic principle, as the universal principle, exists in all communication situations. This paper gives a brief introduction to the pragmatic principles and business English writing principles and illustrates the high consistency between these principles. By analyzing samples, it also points out the instructive significance of pragmatic principles in competitive business English writing. To a certain extent, this provides a theoretical support for the research of business English writing.
\end{abstract}

Keywords: politeness principle; redressive strategies; English competitive business writing principles

\section{INTRODUCTION}

Many philosophers start paying attention to pragmatic principles study after Grice's Cooperative Principle. While in fact, because of inappropriate or impolite language, the misunderstanding and the failure of communication is still quite common. Thus, in order to secure successful communication, Leech proposed another important pragmatic principle, Politeness Principle, in 1983. This principle can be stated as follows: Other things being equal, minimize the expression of impolite beliefs and maximize the expression of polite beliefs. (Leech, 1983: 80)

Centering on the relationship between self and other, Leech analyzes politeness by the use of maxims and proposes four maxims of politeness principle:

Tact maxim:

A. Minimize cost to other

B. Maximize benefit to other

Generosity maxim:

A. Minimize benefit to self

B. Maximize cost to self

Agreement maxim:

A. Minimize disagreement between self and other

B. Maximize agreement between self and other

Sympathy maxim:

*Corresponding author: 363683903@qq.com
A. Minimize antipathy between self and other

B. Maximize sympathy between self and other

(Leech, 1983:132)

However, according to Brown and Levinson, politeness is just an adaptive rational action which is used to achieve the requirement of face. In order to give others faces and save self-face, the best way is to use polite language. Here, face refers to public self-image that every member wants to claim for himself/herself, consisting of two related aspects -- Negative face and Positive face. Negative face refers to the right of the freedom of actions and the need not to be imposed by others. Positive face means the need to be accepted and liked by others and the need to feel that our social group shares common goals. But on many occasions, speech act is an essential threat to face, and the observance of politeness principle is to reduce this threat of face. Therefore, Brown and Levinson stated politeness as "Redressive Strategies". It consists of five redressive strategies: (1) bald on record without redressive strategies; (2) positive politeness; (3) negative politeness; (4) off record; (5) Don't do the FTA.

In business world, business English writing as an important means of communication, most of them need to be written as politely as possible in order to convey and exchange information efficiently and effectively. By doing so, the participants can maintain their harmonious trade relations, remove transaction obstacles and achieve desirable transaction. 


\section{THE APPLICATION OF PRAGMATIC PRIN- CIPLES IN COMPETITIVE BUSINESS ENG- LISH WRITING}

Bobbye puts forwards six principles of business English writing in Business Communication Fundamental, which are six C's: Correctness, which includes completeness and accuracy, means not only proper expression with factual information, accurate figures and exact terms, but also appropriate tone which help to achieve the purpose. Conciseness means most complete message but briefest expression. To achieve conciseness of the business English writing, the writer tries to keep sentence short, and avoid wordy languages and redundancy, or repetition, and eliminate excessive details. Concreteness refers to the specific, definite and general expression rather than vague, abstract one. The style of business English writing should be colorful. The language should be vivid, lively and humor. Consideration is the fifth principle, it means that the writer should take the "You" attitude rather than "I" or "We" attitude and find the best way to express his/ her own understanding and present the message. The last principle is Coherence. It requires logic, complete coherent and flow writing. These are the basic principles of business English writing. And all the business writing should observe them.

Pragmatic principle, as a universal communicating guideline, is highly consistent with the business English writing principle. It is also the guideline of business English writing, and it can promote high quality and efficiency of business communication.

According to Leech's classification of illocutionary functions, business English writing can be classified into four types: competitive writing; convivial writing; collaborative writing and conflictive writing. This paper will focus on the competitive writing. The competitive writing refers to the illocutionary act whose illocutionary functions and social goals are mutually competitive, such as order, request claim and so on. The property of this illocutionary act is "impolite" or "rude". The speaker's real intention is inconsistent with the politeness principle, and thus, the speaker is requested to pay more attention to their speech act and to have a good command of redressive strategies to avoid impoliteness.

Here is a letter for claim to illustrate how these pragmatic principles are appropriately used in business English writing.

\section{Dear Sir,}

We have acknowledged your letter of $12^{\text {th }}$ June, claiming for the spoiled part of the cotton piece goods covering your order No. 216. And we are much surprised at learning that the shipment arrived at your port with some goods damaged.

We have looked up the matter in our records, and found the goods in question were in first class condition when they left here as was evidenced by the Clean Bill of Lading. Every shipment of our exports is strictly inspected by our shipping department before loading, and each package is subject to a careful examination.

After going into the matter carefully we estimate that the damage might be due to rough handling in transit. We therefore would suggest that you lodge a claim with the shipping company who would be held responsible.

Though it is quite out of our control, we are sorry for the inconvenience you have suffered.

At any rate, we thank you for bringing this to our attention and if you feel it necessary we shall be pleased to take the matter up on your behalf with the shipping company concerned.

We hope that this matter will be resolved as soon as possible.

Yours faithfully, ....

The final purpose of this letter is to decline a claim. The real intention of it is refusal, but in order to keep harmonious and cooperative trade relations and also to save face, the writer needs to express his/her own purpose indirectly and politely. Therefore, this letter, from the very beginning, describes a lot about the good quality of the goods, and the well-qualified packing, and also mentions the Clean Bill of Lading as supportive evidence. This arrangement observes politeness principle and redressive strategies. The following is the analysis.

\subsection{Tact maxim}

\section{A. Minimize cost to other \\ B. Maximize benefit to other}

In business English writing, especially the competitive letters, the writer needs to speak tactfully, and change negative tones into positive and softer tones, in order to avoid direct conflict and save others face. This is the manifestation of consideration which reflects the tact maxim and redressive strategies.

The above letter gives detailed information about the declining reasons, which is the usual practice of business declined claim writing. By doing so, the refusal will not be so abrupt and it will be much easier for the receiver to accept the refusal willingly. It embodies the "You" attitude writing principle, and is consistent with the politeness principle's tact maxim. Because the writer describes the declining reasons a lot, he or she, of course leaves much time to the receiver to prepare for the acceptance of the refusal. Thus, from this perspective, the writer minimizes the cost to the receiver, and meanwhile, maximizes benefit to other. At the same time, by friendly providing the alternative solution for the receiver, the receiver preserves himself/herself face and so does the receiver's.

\subsection{Generosity maxim}

A. Minimize benefit to self

B. Maximize cost to self 
This maxim is about the speaker self's benefit and cost It means that the speaker should be generous as much as he/she could. And also it is the consideration writing principle of business letter. In the above letter, the writer spends much time in reexamining the cause of goods damage. What's more, the writer also friendly provides the alternative solution for the receiver. By doing so, the writer tries his/her best to help the receiver to solve this thorny problem corporately, and of course, he/she saves precious time for the receiver. In this letter, when the writer provides the alternative solution for the receiver, he /she writes very carefully and tactfully by using modal verbs, such as might, would in the letter. Because modal verbs are more indirect and subjective, by using them, there is much more room left to the receiver to decide whether he/she will follow the writer's suggestion. From this respect, the receiver has much freedom to make decision without any pressure, that is, the receiver's negative face is saved.

\subsection{Agreement maxim}

A. Minimize disagreement between self and other B. Maximize agreement between self and other

According to this maxim, the speaker should try his/her best to find out the every agreement between himself/herself and avoid any disagreement. This maxim is very useful and helpful, especially when the speaker wants to speak out the disagreement, he/she is requested to show the agreement firstly rather than showing the disagreement directly, otherwise, the speech act will be rude and impolite. Here is the sentence from the above letter: And we are much surprised at learning that the shipment arrived at your port with some goods damaged. This sentence shows that the writer admits the fact of goods damage and also shows his/her regret to this case. And in order to remove this problem, the writer firstly reexamines the goods again to confirm the damage, and then he/she shows many supportive evidences to improve that he/she isn't responsible to this damage. That is to say, the writer reconfirms and readmits the fact actively, and soon later, the writer, from the receiver's standpoint, suggests that the shipping company should be held responsibility. All of these words illustrate that the writer makes every effort to minimize disagreement and maximize agreement between himself/herself and the receiver.

In addition, the writer's skillful arrangement of these words also observes redressive strategies, especially the positive politeness. This strategy is used to save the hearer's positive face rather than threatening, so that the hearer's requested self-image can be in accordance with the speaker's speech action embodied one. Therefore, positive politeness is approach based. The speaker indicates that he/she shares something in common with the hearer, so that he/she can meet the hearer's requirement of positive face. This declined letter shows the agreement at the very beginning and puts forward disagreement at the very end. This arrangement is consistent with the positive politeness. The writer does not only speak out his/her own real intention, but also avoid threatening the writer's positive face. Therefore, it is a win-win solution, and maintains the harmonious trade relation between the writer and the receiver.

\subsection{Sympathy maxim}

A. Minimize antipathy between self and other B. Maximize sympathy between self and other

This is the last but not the least maxim of politeness principle. The key of this maxim is that the speaker shows his/her sympathy to his/her hearer appropriately, and of course, he/she needs to share the hearer's happiness and sorrow honestly and cooperatively. The most important one is that the speaker needs to show his/her sincereness and honesty. For example, in a conversation, if the speaker heard some bad news from the other participant, he/she would show sympathy by saying "I am sorry to hear that." This kind of speech improves that the speaker is not only interested in this topic but also ready to share the hearer's all feelings no matter bad or good. In addition, by observing sympathy maxim the social or psychological distance between the speaker and the hearer is greatly closed. This benefits the maintenance of good relations between the participants.

In this sample letter, the writer writes "we are sorry for the inconvenience you have suffered." By saying this, the writer shows his/her sympathy to the receiver properly and preserves each other's face, when he/she declines the claim. That is because this sentence helps the writer avoid the threat of the writer's own positive face. According to Brown and Levinson, apology threats speaker's positive face. In this letter, the writer offers an apology for the receiver's inconvenience.

\section{CONCLUSION}

Politeness, as a universal principle, exists in all cultures. It is the symbol of human society civilization. And in business world, the participants need to observe both pragmatic principles, especially the politeness principle and redressive strategies, and business English writing principles. By basing on the spirit of honesty, cooperation and politeness, the participants will break down foreign trade barriers and remove the trade obstacles to achieve their anticipated targets. This is especially important in competitive business English writing. From this view, it is valuable and significant to introduce pragmatic principles to standardize business English writing. 


\section{REFERENCES}

[1] Brown, P. \& Levinson, S. C. 1978. Universals in language usage: Politeness phenomena. In E.N. Goody. (Ed), Questions and Politeness: Strategies in Social Interaction. Cambridge, MA: Cambridge University Press, pp.56-289.

[2] He Zhaoxiong. 2000. A New Introduction to Pragmatics. Shanghai: Shanghai Foreign Language Education Press.

[3] He Ziran. 2000. Pragmatics and English Learning.
Shanghai: Shanghai Foreign Language Education Press.

[4] Teng Meirong. 2007. Modern Business English Writing. Beijing: Capital University of Economics and Business Press.

[5] Zhang Tong. 2010. The comparative analysis on politeness principles' micro and macro application. Trade Unions'Tribune, (1): 134-136.

[6] Zhou Ruiqi. 2007. The application of pragmatic principles in business English correspondence. Journal of Guangdong University of Foreign Studies, (1): 92-101. 